\title{
Penggunaan Website dan Internet dalam Pembelajaran
}

\author{
*Said Zulfikar \\ Universitas Islam Negeri Samarinda, Samarinda, Indonesia \\ *Email sayid.fikar46@gmail.com (Corresponding Author)
}

\begin{tabular}{|c|c|}
\hline (A) Check for updates open 0 access (C) & DOI: https://doi.org/10.53621/jider.v1i3.70 \\
\hline Informasi Artikel & \multirow{11}{*}{$\begin{array}{l}\text { ABSTRAK } \\
\text { Penelitian ini bertujuan untuk membangun pemahaman serta menyelesaikan } \\
\text { latihan pembelajaran terhadap pendidik dan untuk mendapatkan data } \\
\text { tentang pemanfaatan website dan internet sebagai pengembangan } \\
\text { pembelajaran di sekolah. Sasaran mendasar dari penelitian tersebut adalah } \\
\text { untuk memutuskan pemanfaatan model pembelajaran yang menggunakan } \\
\text { model berbasis website dan internet. Metode penelitian menggunakan } \\
\text { pendekatan kualitatif studi literatur atau penelitian perpustakaan, membaca } \\
\text { dan memeriksa beberapa artikel nasional untuk menjawab tujuan penelitian } \\
\text { tersebut. Hasil penelitian menemukan pengertian, pemanfaatan, kekurangan } \\
\text { website dan internet dalam pembelajaran. Hal ini sangat mempengaruhi } \\
\text { pengajar dalam menyampaikan materi ajar terhadap pendidik yang telah } \\
\text { diputuskan, serta dapat diterima sesuai dengan sarana dalam model } \\
\text { pembelajaran. Sehingga dapat memberikan waktu kepada pendidik untuk } \\
\text { berpikir dalam sistem pembelajaran. Demikian pula dengan latihan } \\
\text { pembelajaran, pendidik memiliki pilihan untuk mengikuti sistem } \\
\text { pembelajaran dengan baik dan penuh semangat menggunakan website dan } \\
\text { internet sebagai bahan untuk mengungkap data. Hal ini terlihat dari korelasi } \\
\text { jika mereka tidak menggunakan website dan internet dalam menggali data, } \\
\text { maka mereka pada umumnya akan mengalami keterlambatan dalam } \\
\text { memahami pembelajaran. }\end{array}$} \\
\hline Riwayat Artikel: & \\
\hline Diterima: 10 November 2021 & \\
\hline Revisi Akhir: 03 Desember 2021 & \\
\hline Disetujui: 24 Desember 2021 & \\
\hline Terbit: 31 Desember 2021 & \\
\hline & \\
\hline Media berbasis Website & \\
\hline Internet & \\
\hline dan media & \\
\hline & \\
\hline
\end{tabular}

\section{PENDAHULUAN}

Model pembelajaran merupakan suatu metode untuk menghubungkan antara pengajar dan pendidik dalam pembelajaran dan latihan pembelajaran, maka dari itu yang harus diperhatikan adalah ketepatan dalam menggunakan model pembelajaran. Penggunaan model pembelajaran yang tepat dapat menumbuhkan perasaan senang terhadap pendidik untuk belajar, meningkatkan semangat untuk menyelesaikan tugas dan memudahkan untuk memahami topik dalam memberdayakan peserta didik untuk mencapai hasil belajar yang lebih baik. Dengan demikian pengajar harus memiliki pilihan untuk memilih model pembelajaran yang tepat dengan topik yang diajarkan (Sulastri 2017), dalam ukuran sesuai kemampuan pendidik dalam memahami pembelajaran yang terdapat banyak variabel untuk mempengaruhi pencapaian tujuan tersebut. Hal-hal yang perlu diperhatikan dalam meningkatkan model pembelajaran tersebut yaitu pengajar, pendidik, iklim, strategi atau prosedur dan media pembelajaran (Susilana dan Riyana 2008).

Dengan demikian yang menjadi hambatan dalam mewujudkan model pembelajaran tersebut, umumnya adalah keadaan dengan sistem peragaan yang berjalan dan terjadi tidak efektif, banyak waktu, tenaga dan biaya yang terbuang percuma, sedangkan target pembelajaran masih banyak keinginan untuk tercapai dan bahkan merupakan kursus korespondensi antara pengajar dan pendidik. Hal di atas masih sering dijumpai dalam sistem pembelajaran sampai saat ini. Dengan adanya media model penggunaan website dan internet dalam sistem pembelajaran dapat ditingkatkan dengan media pembelajaran yang berbeda dengan aksesibilitas media pembelajaran yang dilakukan di setiap sekolah. Faktor penting yang dapat meningkatkan pendidik dalam hal penggunaan model website dan internet dalam pembelajaran yaitu dengan adanya instruktur sekolah yang baik dan terarah (Mayssara A. Abo Hassanin Supervised 2014, Safaruddin et all, 2020). 
Adapun yang di maksud dengan instruktur sekolah yaitu, instruktur sekolah merupakan pemimpin dari pengelola sistem pembelajaran yang dilakukan di sekolah. Instruktur dapat membuat berbagai situasi wali kelas, memutuskan strategi pembelajaran yang dapat digunakan dalam membangun lingkungan yang besar dan kuat pada pencapaian tujuan pembelajaran yang ideal (Murcia dan Sanchez 2013).

Perkembangan Zaman dan teknologi sangat berpengaruh terhadap berbagai bidang kehidupan masyarakat masa kini, contoh bidang pendidikan. Pendidikan masa kini diharapkan beradaptasi dengan perkembangan teknologi guna mengimbangi generasi masa kini. Siswa memiliki kebutuhan pendidikan yang lebih penting di samping kebutuhan intelektual. Oleh karena itu, metode pembelajaran yang umumnya kurang efektif dan para guru tidak mampu memberikan banyak waktu dan upaya untuk keseluruhan siswa, untuk mengembangkan karakteristik siswa, mencakup aspek-aspek atau kualitas individu siswa, seperti: bakat, motivasi, dan pengetahuan sebelumnya yang telah dimiliki (Rehalat 2016).

Salah satu model pembelajaran yang membantu siswa dalam melakukan pembelajaran serta mempelajari latihan adalah dengan model penggunaan website dan internet (lik Novianto 2003). Pembelajaran dengan memanfaatkan model penggunaan website dan internet dalam sistem pembelajaran, ternyata menjadi alasan bagi pendidik untuk berperan penting dalam menyelesaikan latihan-latihan pembelajaran di sekolah. Meskipun pengajar memiliki wawasan yang lebih tanpa didukung oleh media pembelajaran yang baik, sistem pembelajaran akan melelahkan dan kurang memikat peserta didik. Oleh karena itu, dalam pembelajaran penting untuk memiliki media model penggunaan website dan internet. Dengan media ini, setiap pendidik dapat memanfaatkan web sesuai dengan kebutuhan pembelajaran nya. Selain itu, pemanfaatan model penggunaan website dan internet sebagai media pembelajaran sangat membantu pendidik dalam mendapatkan data informasi, mengirim tugas sekolah melalui email, dll (Kaliky 2013).

Selain membantu dalam menyelesaikan tugas di sekolah, pendidik juga dapat mempermudah dalam menyampaikan pembelajaran. Penggunaan situs dan media web sangat penting untuk pelaksanaan pembelajaran yang baik (Alaswati, Rahayu, dan Raffy Rustiana 2016), sehingga sistem pembelajaran akan semakin efektif. Pemanfaatan model penggunaan website dan internet dalam sistem pembelajaran pendidik dapat bekerja sama dengan pengajar menggunakan beberapa aplikasi seperti Whatsapp, Zoom, Meet, Google Study Hall. Pembelajaran ini merupakan pengembangan instruktif agar penyampaian materi melalui online dapat dipahami dan berjalan lebih efektif. Hal ini bertujuan sebagai salah satu ilustrasi pengajar yang memanfaatkan media elektronik pembelajaran atau mengatur koneksi (membaca, mengunjungi, video call) (Hartawan dan Sudiarsa 2019).

Model pembelajaran yang menggunakan model website dan internet ini merupakan model pembelajaran yang dapat digunakan untuk membekali pendidik dengan pemahaman materi yang sulit sampai yang sederhana dan dapat digunakan untuk menentukan sejauh mana pendidik memahami materi yang dijelaskan oleh pengajar (Anitah 2013). Tugas model penggunaan website dan internet di sini adalah memberikan aset pembelajaran dengan koneksi terhadap berbagai aset pembelajaran yang dapat diakses dengan website dan internet. Model penggunaan website dan internet dalam pembelajaran berfungsi untuk memperluas jumlah peminat dan komunikasi antara pengajar dan pendidik (Budi ningsih 2015). Pertukaran informasi atau korespondensi yang dapat membangun hubungan antara pengajar dan pendidik dapat dijangkau kapan saja, hal itu mengisyaratkan bahwa pendidik dapat memanfaatkan sistem media pembelajaran yang diberikan terhadap website dan internet dapat dijangkau kapan pun sesuai dengan pemahaman pendidik, sehingga keberadaan yang mereka hadapi dalam menemukan aset pembelajaran dapat bertahan dalam jangka waktu yang lama (Widodo 2005). 
Pemanfaatan media pembelajaran dalam ukuran pengajaran memiliki beberapa keuntungan yaitu, membuat pemahaman pendidik terhadap tambahan dalam wawasan ilmu sehingga dapat mendorong inspirasi belajar siswa. Dengan demikian materi yang ditampilkan lebih jelas sehingga siswa dapat memahami dan mendominasi tujuan dengan baik dan pendidik akan lebih banyak melakukan kerja sama dalam memahami pembelajaran serta menyelesaikan latihan dalam pembelajaran (Aprizal dan Aprian 2013).

Tujuan penggunaan model website dan internet dalam pembelajaran adalah untuk membangun pemahaman serta menyelesaikan latihan pembelajaran terhadap pendidik dan untuk mendapatkan data tentang pemanfaatan website dan internet sebagai pengembangan pembelajaran di sekolah. Sasaran mendasar dari penelitian tersebut adalah untuk memutuskan pemanfaatan model pembelajaran yang menggunakan model berbasis website dan internet (M.Izman Herdiansyah 2013).

\section{METODE PENELITIAN}

Jenis penelitian yang digunakan dalam penggunaan model website dan internet dalam pembelajaran adalah dengan menggunakan pendekatan kualitatif studi literatur atau penelitian perpustakaan, membaca dan memeriksa beberapa artikel nasional untuk menjawab tujuan penelitian tersebut. Penelusuran artikel menggunakan (Google Scholar, DOAJ). Dalam pendekatan kualitatif, informasi yang muncul lebih banyak berupa kata-kata, bukan kumpulan dari susunan angka (Darmalaksana 2020). Pemanfaatan tulisan, baik dalam eksplorasi kualitatif maupun dalam pemeriksaan subjektif mengambil bagian yang signifikan dan berbeda dalam penelitian tentang pemanfaatan website dan internet dalam pembelajaran sebagai aturan, hal tersebut digunakan karena untuk membedakan konsekuensi dari penelitian masa lalu hingga masa sekarang, khususnya penemuan berbeda yang telah ditemukan atau belum ditemukan dengan keadaan tertentu yang harus diperoleh dengan cara yang efektif sehingga memberi dampak positif terhadap penggunaan model website dan internet dalam pembelajaran.

Analisis dilakukan pada artikel ilmiah yang terkait pembelajaran dengan menggunakan model website dan internet dalam pembelajaran, pemanfaatan website dan internet dalam lingkup pendidikan, dan manfaat penggunaan model pembelajaran dalam website dan internet. Peneliti kemudian menganalisis dan mendeskripsikan hasil dari temuan yang ada berdasarkan hasil kajian dan pengamatan, penggalian sumber akan diselesaikan dengan mengumpulkan teori dan pembahasan tentang masalah yang diidentifikasi dengan pemanfaatan situs dan web dalam pembelajaran (Widayati 2014).

\section{HASIL DAN PEMBAHASAN}

\section{Pengertian model penggunaan website dan internet dalam pembelajaran}

Penggunaan model website dan internet dalam pembelajaran merupakan salah satu model pembelajaran yang berkaitan dengan data informasi berbasis website dan internet untuk membantu pelaksanaan pendidikan serta pembelajaran, sehingga dapat membantu pengajar dan pendidik dalam menumbuhkan pembelajaran yang lebih giat (Rahman, Munawar, dan Berman 2016). Sementara itu, website dan internet memiliki kepentingan hubungan dengan berbagai jenis jaringan yang ada di dunia ini dan memiliki kerangka kerja dengan berbagai aplikasi, serta mendorong untuk terus mencari informasi dalam gadget (Ayu, Sari, dan Muhaqiqin 2021).

\section{Manfaat penggunaan model website dan internet dalam pembelajaran}

Hadirnya inovasi situs dan web tidak dapat dipungkiri yang membawa banyak perubahan pada seluruh bagian kehidupan individu di berbagai belahan dunia. Banyak sekali manfaat yang bisa didapatkan dengan penggunaan model pembelajaran website dan internet ini. Salah satunya dalam bidang pendidikan. Adapun manfaat dari model tersebut, yaitu : (Haryanto 2007, ) 


\section{Memberdayakan komunikasi pembelajaran}

Untuk latihan pembelajaran dimana aset pembelajaran dengan mudah diakses oleh setiap instruktur dan pendidik memiliki pilihan untuk berkomunikasi kapanpun dan dimanapun. Dengan begitu kenyamanan ini menyebabkan pendidik mempresentasikan tugasnya kepada guru lebih efektif.

\section{Dapat menjangkau siswa dalam cakupan seluruh dunia/perluasan yang sangat luas}

Manfaat website dan internet dalam pembelajaran dapat disesuaikan dengan jumlah (pendidik) yang diperoleh dengan pengumpulan data yang menjadi lebih luas dan lebih beragam. Yang pasti, keberadaan tidak sedikit pun menjadi hambatan dalam penggunaan website dan internet yang menyertainya. Kesempatan untuk belajar benar-benar terbuka bagi setiap individu yang membutuhkannya. Jadi, siapa pun, di mana pun, dan kapan pun seseorang akan melihatnya mudah untuk melakukan latihan pembelajaran.

\section{Memberikan kemudahan dalam menyempurnakan serta menyimpan bahan pembelajaran}

Kehadiran website dan internet membantu akomodasi yang didapat dalam kemajuan bahan pembelajaran. Ini adalah salah satu kelebihan website dan internet untuk pemahaman belajar serta latihan di sekitar/sekolah. Latihan-latihan pengembangan materi pembelajaran lebih lanjut seperti yang dirujuk di atas harus dimungkinkan secara efektif, peningkatan dalam teknik pembelajaran juga dapat dibuat tergantung pada kritik siswa dan hasil penilaian dari para ahli.

\section{Kekurangan dari penggunaan model website dan internet dalam pembelajaran}

Selain banyaknya manfaat yang terdapat dalam model penggunaan website dan internet, ternyata masih ada juga terdapat kekurangan dalam penggunaan model tersebut. Hal ini menjadi introspeksi diri untuk bisa membedakan atau mengambil baik buruknya mengenai penggunaan model website dan internet dalam pembelajaran (Abidin 2016). Adapun yang menjadi kekurangan terhadap model pembelajaran tersebut, yaitu:

1. Keterbatasan akses internet

Salah satu kekurangan metode pembelajaran berbasis website dan internet ini adalah terbatasnya akses internet. Jika pendidik berada di daerah yang tidak mendapatkan jangkauan internet stabil, maka akan sulit bagi pendidik untuk mengakses pembelajaran yang terdapat di website. Hal ini tentunya masih banyak terjadi di Indonesia mengingat beberapa daerah 3T (tertinggal, terdepan, dan terluar) masih belum terjangkau akses internet. Selain itu, harga pemakaian data internet juga masih dirasa cukup mahal untuk beberapa kalangan masyarakat Indonesia.

2. Berkurangnya interaksi dengan pengajar

Beberapa metode pembelajaran berbasis website dan internet bersifat satu arah. Hal tersebut menyebabkan interaksi pengajar dan pendidik menjadi berkurang sehingga akan sulit bagi pendidik untuk mendapatkan penjelasan lebih lanjut mengenai materi yang susah dipahami.

3. Pemahaman terhadap materi

Materi yang diajarkan dalam model pembelajaran berbasis website dan internet direspon berdasarkan tingkat pemahaman yang berbeda-beda, tergantung kepada kemampuan pendidik. Beberapa orang mungkin dapat menangkap materi dengan lebih cepat hanya dengan membaca, namun ada juga yang membutuhkan waktu lebih lama sampai benarbenar paham. Bahkan ada juga yang membutuhkan penjelasan dari orang lain agar dapat memahami materi yang dipelajari.

4. Minimnya Pengawasan dalam Belajar

Kurangnya pengawasan dalam melakukan pembelajaran secara daring membuat penggunaan model pembelajaran berbasis website dan internet kadang kehilangan fokus. Dengan adanya kemudahan akses, beberapa pengguna cenderung menunda-nunda waktu 
belajar. Perlu kesadaran diri sendiri agar proses belajar dengan metode daring menjadi terarah dan mencapai tujuan.

\section{KESIMPULAN}

Kesimpulan penelitian ini yaitu terdapat pengaruh yang signifikan terhadap pengembangan proses pembelajaran dengan menggunakan model website dan internet sehingga memberikan hasil belajar yang lebih efektif. Dengan adanya penggunaan model website dan internet dalam pembelajaran memberikan dampak positif bagi pengajar maupun pendidik, oleh karena itu model pembelajaran berbasis website dan internet bertujuan untuk membangun pemahaman serta menyelesaikan latihan pembelajaran terhadap pendidik dan untuk mendapatkan data tentang pemanfaatan website dan internet sebagai pengembangan pembelajaran di sekolah.

\section{UCAPAN TERIMA KASIH}

Terima Kasih kepada Bapak Dr. Moh. Salehudin, S,PdI. M.Pd selaku Dosen Pengampu mata kuliah 'Teknologi Dan Media Pembelajaran' yang telah membimbing dalam kegiatan menulis artikel sesuai dengan tema mata kuliah.

\section{DAFTAR PUSTAKA}

Affiifi. 2014. “Supervisi Akademik Kepala Sekolah.” Paper Knowledge . Toward a Media History of Documents, 2-8.

Alaswati, Sri, Setya Rahayu, and Eunike Raffy Rustiana. 2016. "Evaluasi Pelaksanaan Pembelajaran Kurikulum 2013 Pjok." Journal of Physical Education and Sports 5 (2): $1-119$.

Aminah. 2016. "Model Pembelajaran Pemrosesan Informasi." Jurnal Pendidikan Ilmu Sosial 23 (2): 1.

Ani. 2014. "Penelitian Tindakan Kelas." Jurnal Pendidikan Akuntansi Indonesia 6 (1): 142. https:/ / doi.org/10.21831/jpai.v6i1.1793.

AY, Niken, Aprizal, and Hervanus Muharam Fajri Riki Aprian. 2013. “Analisis Pemanfaatan Situs Web Universitas Islam Negeri (Uin) Syarif Hidayatullah Menggunakan Metode Pieces." In , 1-53.

Ayu, Mutiara, Fatimah Mulya Sari, and Muhaqiqin Muhaqiqin. 2021. "Pelatihan Guru Dalam Penggunaan Website Grammar Sebagai Media Pembelajaran Selama Pandemi." Al-Mu'awanah: Jurnal Pengabdian Kepada Masyarakat 2 (1): 49-55.

Budiningsih, C. Asri. 2015. "Karakteristik Siswa Sebagai Pijakan Dalam Penelitian Dan Metode Pembelajaran." Jurnal Cakrawala Pendidikan 1 (1): 160-73. https://doi.org/10.21831/cp.v1i1.4198.

Budiningsih, C. Asri. 2015. “Karakteristik Siswa Sebagai Pijakan Dalam Penelitian Dan Metode Pembelajaran." Jurnal Cakrawala Pendidikan 1 (1): 160-73. https:/ / doi.org/10.21831/cp.v1i1.4198.

Cepi Riyana. 2008. “Komputer Dan Media Pendidikan Di Sekolah Dasar.” Wacana Prima, 5-35.

Darmalaksana, Wahyudin. 2020. “Metode Penelitian Kualitatif Studi Pustaka Dan Studi Lapangan." Pre-Print Digital Library UIN Sunan Gunung Djati Bandung, 1-6.

Eunike Raffy Rustiana. 2016. “Evaluasi Pelaksanaan Pembelajaran Kurikulum 2013 Pjok." Journal of Physical Education and Sports 5 (2): 1-119.

Hartawan, I Nyoman Buda, and I Wayan Sudiarsa. 2019. “Analisis Kinerja Internet of Things Berbasis Firebase Real-Time Database." Jurnal RESISTOR (Rekayasa Sistem Komputer) 2 (1): 6-17. https:/ / doi.org/10.31598/jurnalresistor.v2i1.371. 
Haryanto, D. 2007. “inovasi pembelajaran Editor : Dini Putri Haryanto.” Perspektif Ilmu Pendidikan 16: 2-18.

Iik Novianto. 2003. "Perilaku Penggunaan Internet Di Kalangan Mahasiswa." Studi Deskriptif Tentang Perilaku Penggunaan Internet Dikalangan Mahasiswa Perguruan 148: 1-40.

Kaliky, Pahrul Idham. 2013. "Pemanfaatan Internet Dalam Pembelajaran Mahasiswa." Jurnal Komunikasi KAREBA 2 (1): 110-20.

Kilian Ernesto Sanchez. 2013. "Peranan Komunikasi Dalam Pendidikan." Applied Microbiology and Biotechnology 85 (1): 2071-79.

Mayssara A. Abo Hassanin Supervised, Affiifi. 2014. "Supervisi Akademik Kepala Sekolah." Paper Knowledge . Toward a Media History of Documents, 2-8.

Muhaqiqin. 2021. "Pelatihan Guru Dalam Penggunaan Website Grammar Sebagai Media Pembelajaran Selama Pandemi." Al-Mu'awanah: Jurnal Pengabdian Kepada Masyarakat 2 (1): 49-55.

Murcia, Juan Cralos, and Kilian Ernesto Sanchez. 2013. "Peranan Komunikasi Dalam Pendidikan." Applied Microbiology and Biotechnology 85 (1): 2071-79.

Pahrul Idham. 2013. "Pemanfaatan Internet Dalam Pembelajaran Mahasiswa." Jurnal Komunikasi KAREBA 2 (1): 110-20.

Rahman, Syaiful, Wahid Munawar, and Ega T. Berman. 2016. "Pemanfaatan Media Pembelajaran Berbasis Website Pada Proses Pembelajaran Produktif Di Smk." Journal of Mechanical Engineering Education 1 (1): 137. https:/ / doi.org/10.17509/jmee.v1i1.3746.

Rehalat, Aminah. 2016. “Model Pembelajaran Pemrosesan Informasi." Jurnal Pendidikan Ilmu Sosial 23 (2): 1.

Riki Aprian. 2013. "Analisis Pemanfaatan Situs Web Universitas Islam Negeri (Uin) Syarif Hidayatullah Menggunakan Metode Pieces." In , 1-53.

Safaruddin, S., Degeng, I., Setyosari, P., \& Murtadho, N. (2020). The Effect of PjBL with WBL Media and Cognitive Style on Studentsâ€тM Understanding and ScienceIntegrated Concept Application. Jurnal Pendidikan IPA Indonesia, 9(3), 384-395. doi: https:/ / doi.org/10.15294/jpii.v9i3.24628

Sulastri, Tuti. 2017. “Analisis Kepuasan Mahasiswa Terhadap Kinerja Dosen.” Optimal: Jurnal Fakultas Ekonomi Universitas Islam “45” Bekasi 10 (2): 167-84.

Susilana, Rudi \&, and Cepi Riyana. 2008. “Komputer Dan Media Pendidikan Di Sekolah Dasar." Wacana Prima, 5-35.

T. Berman. 2016. "Pemanfaatan Media Pembelajaran Berbasis Website Pada Proses Pembelajaran Produktif Di Smk." Journal of Mechanical Engineering Education 1 (1): 137. https:/ / doi.org/10.17509/jmee.v1i1.3746.

Tuti. 2017. “Analisis Kepuasan Mahasiswa Terhadap Kinerja Dosen.” Optimal: Jurnal Fakultas Ekonomi Universitas Islam “45” Bekasi 10 (2): 167-84.

Wahyudin. 2020. “Metode Penelitian Kualitatif Studi Pustaka Dan Studi Lapangan.” PrePrint Digital Library UIN Sunan Gunung Djati Bandung, 1-6.

Wayan Sudiarsa. 2019. “Analisis Kinerja Internet of Things Berbasis Firebase Real-Time Database.” Jurnal RESISTOR (Rekayasa Sistem Komputer) 2 (1): 6-17. https:/ / doi.org/10.31598/jurnalresistor.v2i1.371.

Widayati, Ani. 2014. "Penelitian Tindakan Kelas." Jurnal Pendidikan Akuntansi Indonesia 6 (1): 1-42. https: / / doi.org/10.21831/jpai.v6i1.1793. 